\title{
Wonder weed plans fail to flourish
}

\author{
The first of four weekly articles on biofuels looks at how investment in jatropha is \\ slowing, as investors realize that basic research is needed.
}

\section{THE BUSINESS OF BIOFUELS}

The promise of green gold is fading from Jatropha curcus, a shrub that thrives in arid conditions and whose seeds yield a diesel-like oil. Many had seen it as a potential saviour for marginal lands, a plant that could lift developing countries out of poverty and into a sustainable oily future.

Just last year, some analysts were predicting that the area planted with jatropha worldwide - at the time, 721,000 hectares - would rise as high as 22 million hectares by 2014 . The Jatropha Alliance, an advocacy group based in Berlin, was estimating that investments of up to US $\$ 1$ billion could be expected annually. More than 130 companies were in the race, dominated by D1 Oils of London, which in 2007 had landed a \$160-million deal with oil giant BP.

But this July, BP and D1 announced that their deal was off. And of 140 investments made in biofuels so far this year, says analyst Harry Boyle of London-based New Energy Finance, only four or five have been in jatropha projects. "Jatropha has gone very quiet," he says.

What happened? It's difficult to untangle the impacts of the global financial downturn from disappointment with jatropha in particular, says Rob Bailis, an environmental scientist at Yale University. But "over the past three years, the investment got way ahead of the plant science", he says.

Early investors are now realizing the plant's limitations. Jatropha can live in very dry conditions, but doesn't necessarily yield a lot of seeds. The plant takes three years or more to reach maturity, requiring care along the way. And jatropha seedlings are often not well-suited to the climate in which they are planted.

Even supporters acknowledge that the allure of jatropha is fading somewhat. "This year, a lot of projects did not continue," admits Thilo Zelt, director of the Jatropha Alliance.

One blow came with the publication of a controversial paper in June, in which a team led by Arjen Hoekstra at the University of Twente in the Netherlands suggested that jatropha needs more water than other bioenergy crops, such as maize (corn), to produce the same amount of oil (W. Gerbens-Leenes et al. Proc. Natl Acad. Sci. USA 106, 10219-10223; 2009). Jatropha

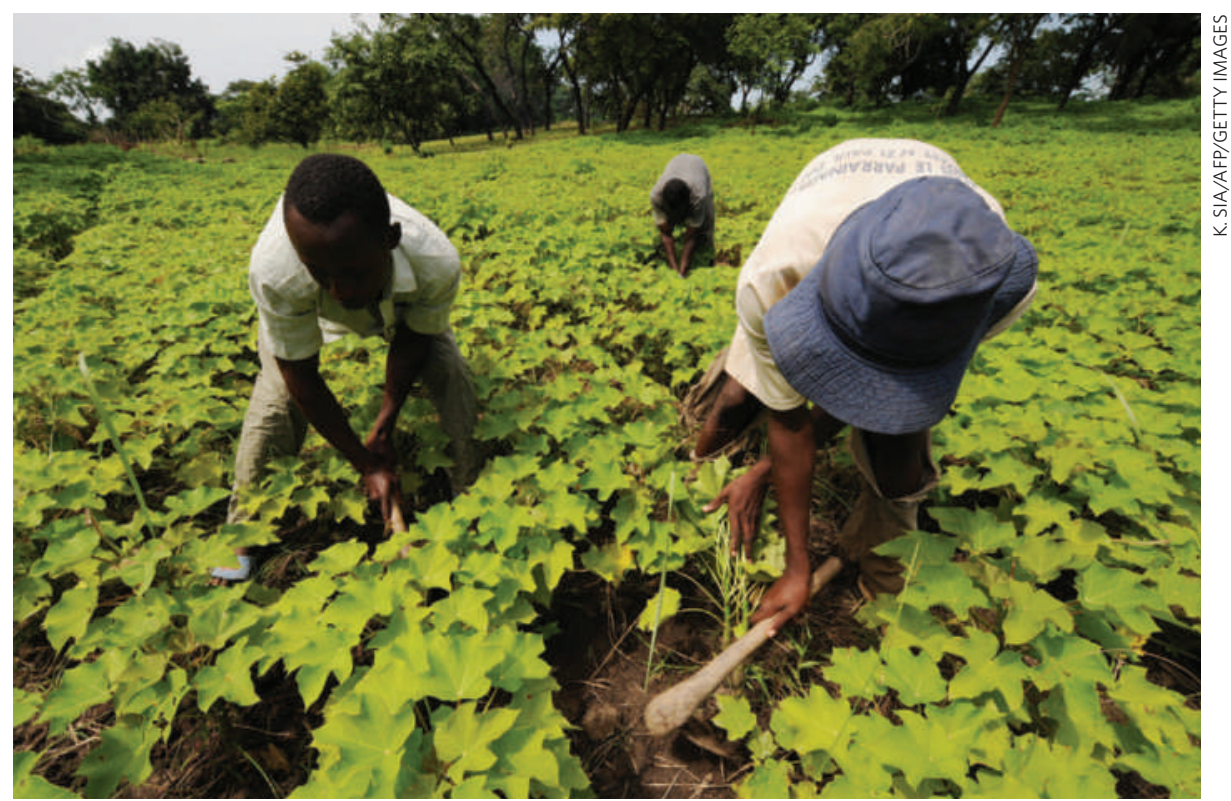

Billion-dollar investment plans for large-scale farming of the jatropha biofuel crop are on hold.

had nearly four times the water footprint of sugar-cane ethanol, for instance.

Critics point out what they see as flaws in that analysis, including the fact that it is difficult to compare jatropha, which is wild, with crops such as maize that were domesticated for optimal use thousands of years ago. In addition, the analysis looked at a small number of plantations, all of which had young trees, which could skew the conclusions, says Bart Muys, a forest ecologist at the University of Leuven in Belgium. But Hoekstra says that more thought needs to be given o variables such as where jatropha is planted and how it is harvested. "Jatropha was the hallelujah crop," he says, but in reality "it is just another crop with its own characteristics".

The split between D1 Oils and BP has hurt jatropha's reputation as a good business investment, says Boyle. In a statement, BP spokeswoman Sheila Williams said that "the decision to pull out of this is purely based on economics and a decision to focus on key strategic areas", such as sugar-cane ethanol from Brazil, cellulosic ethanol from the United States and biobutanol. In the meantime, D1 Oils has shifted from planting jatropha to focusing on basic research
— including starting a breeding programme to develop seeds with high oil yields, says Henk Joos, the company's head of plant science.

Another company concentrating on basic science is SG Biofuels, based in Encinitas, California. It has collected samples from jatropha plants growing wild in different environments and is creating a library of genetic material from which it intends to develop enhanced seed strains to test, says chief executive Kirk Haney.

Eventually, jatropha might prove more useful on a local scale. For instance, Diligent Energy Systems, a company based in Eindhoven, the Netherlands, has set up small-scale operations in Tanzania, where it provides jatropha seeds for farmers to plant among other crops or on spare land that is unsuitable for food crops. The farmers are guaranteed a price for the oil seeds they produce, and so have an incentive to tend the crop and harvest it carefully, says company founder Ruud van Eck. Some 5,000 farmers are involved, he says, with a total of 3,500 hectares of jatropha planted between them. "The idea is to grow to 10,000 by the end of this year," he says.

In other countries, jatropha has yet to capture local support. In the Lao People's Democratic Republic, farmers have been bombarded with seeds and promotional material from companies but received little to no support, says 
Jakob Rietzler of the Lao Institute for Renewable Energy in Vientiane. As a result, he says, the jatropha they planted reached harvest at the same time as the rice crops. "Farmers neglect their jatropha seeds because they have to harvest their rice," he says.

In India, where much of the jatropha hype originated, success will come only if a conservative, realistic approach is adopted at the beginning, says Pushpito Ghosh, director of the Central Salt and Marine Chemicals Research Institute in Bhavnagar. Biodiesel from his institute's jatropha project (see Nature 449, 652-655; 2007) has been used in test cars belonging to the project and in collaboration with General Motors. Ghosh's team has been working to improve the genetic stock of their jatropha, and is about to embark on a life-cycle analysis of how much biodiesel jatropha can generate from a 50-hectare plot.

Even so, "it would be premature to call [jatropha] a success in India", says Ghosh. "It is still in the take-off stage."

He sees the hype and subsequent disappointment surrounding jatropha as a weeding-out process, leaving behind smaller, more profes-

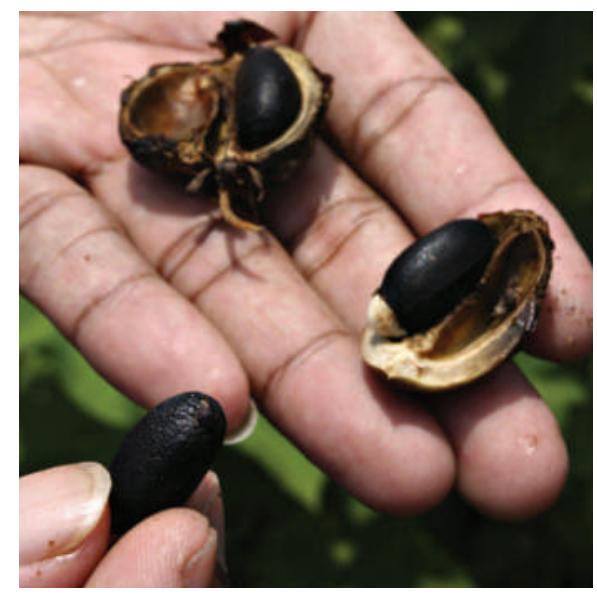

More oil per seed is the goal.

sional players. These include the Australiabased Jatoil, which in August announced a memorandum of understanding with the European biofuel producer PT Waterland. The deal is expected to give Jatoil between 1,000 and 2,000 hectares of established jatropha-bearing land in Java. And China, one of the world's leading biofuel manufacturers, is also taking an inter- est in jatropha, with 105,000 hectares planted in the country by 2008 and a total of 700,000 predicted by 2015 .

The next year is likely to see more basic research into the crop. Muys and his team, for instance, have analysed global land suitability and developed a high-resolution map to show where jatropha might grow best; Madagascar, Tanzania and Ethiopia are likely candidates. Meanwhile, Bailis is conducting jatropha lifecycle analyses to account for land-use change in India and Brazil. Zelt says that seeds optimized to produce more oil will be entering the market in the coming months, and the first real secondgeneration plants will be planted next year.

So although jatropha may not be a saviour plant, transforming vast quantities of desert land into biofuel-producing moneymakers, it is likely to find its niche as a local alternative in certain developing countries. "We need to find ways to use local business resources more efficiently," says Jeremy Woods from Imperial College London's Centre for Environmental Policy. "And jatropha can play a big part in that."

Katharine Sanderson

NEXT WEEK: BIOALGAE 